\title{
Infantile Cerebellar Pilocytic Astrocytoma with Autism Spectrum Disorder
}

\author{
Koji Adachi, Yasuo Murai and Akira Teramoto \\ Department of Neurosurgery, Graduate School of Medicine, Nippon Medical School \\ Department of Neurosurgery, Nippon Medical School
}

\begin{abstract}
The etiology of autism remains unclear, but relationships to cerebellar factors have been reported. We report 2 cases of infantile cerebellar pilocytic astrocytoma in children with autism spectrum disorder. Cerebellar tumors may be related to the pathogenesis of autism. (J Nippon Med Sch 2012; 79: 228-231)
\end{abstract}

Key words: infantile pilocytic astrocytoma, autism, autism spectrum disorder

\section{Introduction}

Autism is a type of neurodevelopmental disorder involving retardation of socialization and communication abilities. The underlying cause remains largely unknown, but a close relationship may exist between autism and cerebellar lesions, with some authors reporting autistic patients with cerebellar lesions. We report herein 2 cases of cerebellar pilocytic astrocytoma arising in children with autism spectrum disorder (ASD).

\section{Case Reports}

\section{Case 1}

A 5-year-old boy was referred to our hospital because of gait disturbance. He had a history of autism diagnosed according to Diagnostic and Statistical Manual of Mental Disorders, 4th Edition, Text Revision (DSM-IV-TR), and his intelligence quotient (IQ) was 69 on admission. Physical examination revealed a head circumference of $55 \mathrm{~cm}$. Neurological examination detected cerebellar ataxia and dysmetria. Papilledema was evident bilaterally. Computed tomography (CT) of the head showed a cerebellar cyst associated with a nodular tumor and obstructive hydrocephalus. Magnetic resonance imaging (MRI) disclosed strong, homogenous enhancement of the tumor with no enhancement of the cyst wall (Fig. 1A). The tumor was removed surgically, and histopathological examination confirmed pilocytic astrocytoma (Fig. 2A). Cerebellar signs and papilledema resolved postoperatively, but the IQ and autistic behaviors remained unchanged.

\section{Case 2}

A 6-year-old girl was brought to the hospital because of headache. Asperger syndrome was diagnosed according to DSM-IV-TR, and the IQ was 92 on admission. A family history of ASD was identified. Her 15-year-old brother had received a diagnosis of autism, and her 39-year-old father had high-functioning autism. Autism-spectrum quotients ${ }^{2}$

Correspondence to Koji Adachi, MD, DMSc, Department of Neurosurgery, Nippon Medical School Musashi Kosugi Hospital, 1-396 Kosugi-cho, Nakahara-ku, Kawasaki, Kanagawa 211-8573, Japan

E-mail: adachi@nms.ac.jp

Journal Website (http://www.nms.ac.jp/jnms/) 


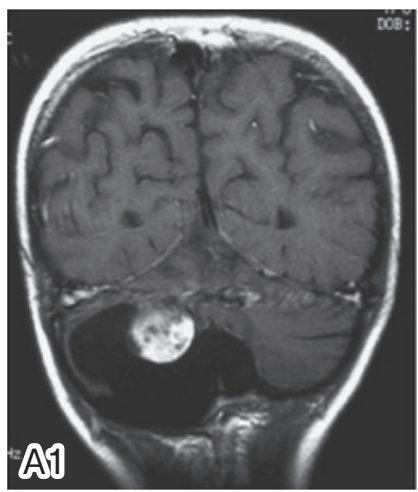

A) Case 1
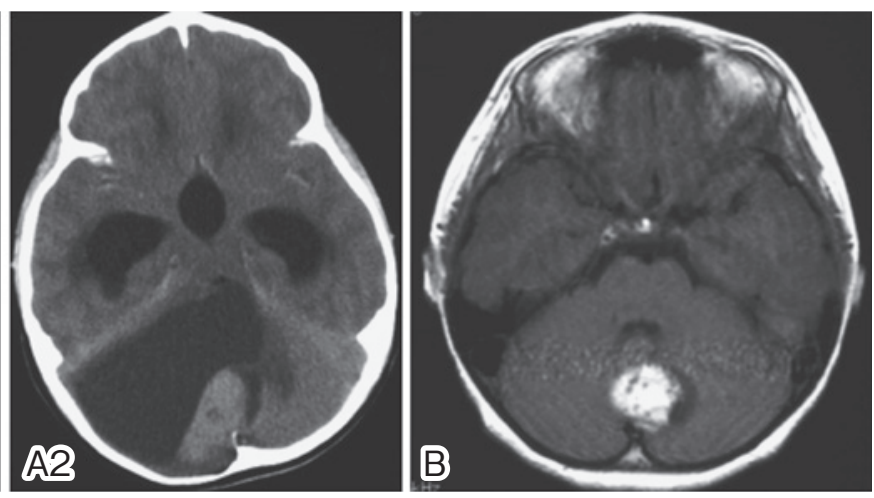

Fig. 1

Magnetic resonance image (A1) and computed tomogram (A2) for a 5-year-old boy who presented with gait disturbance show an enhancing nodule with a large cyst in the cerebellum. Obstructive hydrocephalus and thinning of the occipital bone are observed.

B) Case 2

Magnetic resonance image of a 6-year-old girl showing a partially enhancing mural nodule with a peritumoral cyst in the cerebellar vermis.
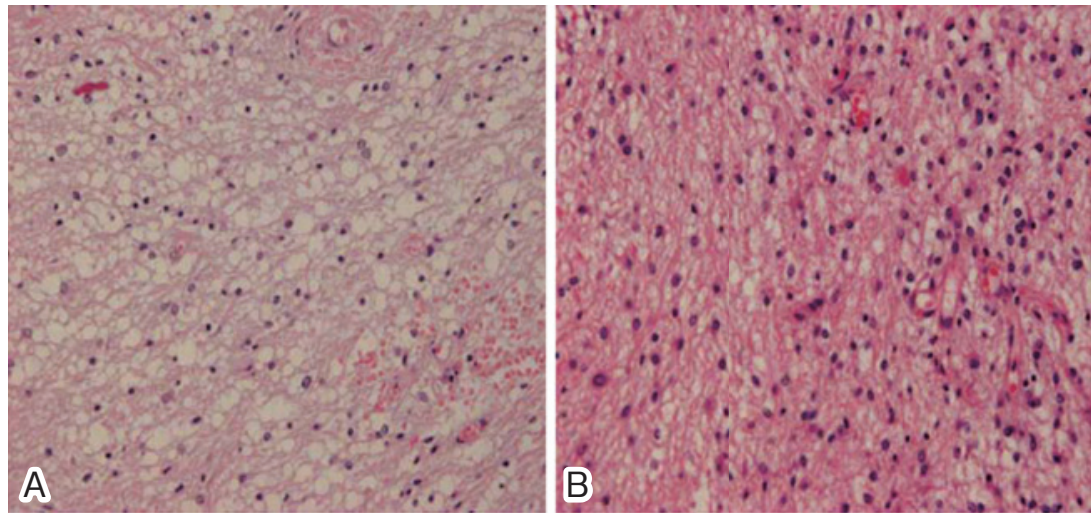

Fig. 2

A) Case 1

Vacuolated cells with small, round nuclei are present in the spongy area. A Rosenthal fiber is apparent. $(\mathrm{H} \& \mathrm{E}, \times 40)$

B) Case 2

Cells with small nuclei showing microcysts. Eosinophilic granular bodies are observed. Tumor cells are positive for glial fibrillary acidic protein (not shown). (H \& E, × 40)

in these family members were 42 and 34 , respectively. The patient showed no neurological deficits. Both CT and MRI showed a partially enhancing nodule and cyst in the cerebellar vermis (Fig. 1B). No abnormalities other than the vermis lesion were identified. She underwent surgery, and the nodule was totally resected. The histological diagnosis was pilocytic astrocytoma (Fig. 2B). Postoperatively, headache resolved completely, but the ASD remained unchanged.

\section{Discussion}

Autism is a neurodevelopmental disorder mainly affecting children which is characterized by language problems and communication deficits. Impaired social interactions, lack of communication skills and restricted and repetitive behaviors are key symptoms. ASD is a clinical entity that includes autism and the wide variety of conditions between 
"normal" and autism.

ASD includes classical autism, Asperger syndrome, and pervasive developmental disorder not otherwise specified and is diagnosed according to the criteria of DSM-IV-TR ${ }^{1}$. Autism spectrum index is also used to diagnose ASD, and the cut-off value for discriminating ASD from normal is $33^{2.3}$.

The etiology of ASD remains unclear, but strong relationships have been documented with such factors as genetic disorders (tuberous sclerosis, neurofibromatosis ${ }^{5}$, and fragile $\mathrm{X}$ syndrome ${ }^{6}$ ), metabolic disorders (pheylketouria ${ }^{7}$ and Lesch-Nyhan syndrome ${ }^{8}$ ), brain anomalies (congenital hydrocephalus ${ }^{9}$ ), infections (rubellavirus, cytomegalovirus, and influenzavirus $)^{10-13}$, druginduced disorders (antiepileptic agents ${ }^{14}$, alcohol ${ }^{15}$, and thalidomide ${ }^{16}$ ), and perinatal disorders ${ }^{17}$. ASD sometimes shows physical abnormalities, such as macrocephaly ${ }^{18}$, and high blood serotonin levels ${ }^{19}$.

Cerebellar and brainstem hypoplasia, abnormality of the corpus callosum, and volume reduction of the cingulate gyrus have also been associated with $\mathrm{ASD}^{20}$. These changes have been observed during fetal development $t^{21,22}$. Other authors have reported that autism is probably caused by brain tumors and brain injuries ${ }^{23-25}$.

In children, congenital hypoplasia of the cerebellum (particularly the vermis) is reportedly often accompanied by a wide range of neurodevelopmental disorders ${ }^{26-29}$. Other reports on the relationship between autism and cerebellar lesions have noted low numbers of Purkinje cells ${ }^{30,31}$, reductions in Purkinje cell size $\mathrm{s}^{32}$, and dysregulation of Reelin and Bcl-2 proteins, which are related to Purkinje cell migration ${ }^{33}$. Studies of astrocytomas of the posterior fossa have revealed the presence of cognitive deficits after tumor removal ${ }^{34}$. ASD thus does not appear as a functional disease, but rather as an organic disorder. A relationship may exist between autism and the cerebellum.

Autism may not be a symptom resulting from tumor compression, because no changes were seen in our cases after the removal operations. Furthermore, we observed no postoperative exacerbation of autistic symptoms. No evidence of histological changes to the normal cerebellum was apparent in our cases, but we removed only neoplastic lesions and did not analyze normal tissue. Histopathological characteristics in these cases were representative of typical cerebellar pilocytic astrocytoma.

Pilocytic astrocytoma is World Health Organization grade I tumor, is characterized by slow progression, and may be a congenital tumor when found in children, as in the present cases. There may be a relationship between $\mathrm{ASD}$ and infantile cerebellar pilocytic astrocytoma.

\section{References}

1. American Psychiatric Association, Task Force on DSM-IV: Diagnostic and statistical manual of mental disorders:DSM-IV-TR, 4th ed, 2000; American Psychiatric Association, Washington DC.

2. Baron-Cohen S, Wheelwright S, Skinner R, Martin J, Clubley E: The autism-spectrum quotient (AQ): evidence from Asperger syndrome/high-functioning autism, males and females, scientists and mathematicians. J Autism Dev Disord 2001; 31: 5-17.

3. Wakabayashi A, Baron-Cohen S, Wheelwright S, Tojo Y: The autism-spectrum quotient (AQ) in Japan: a cross-cultural comparison. J Autism Dev Disord 2006; 36: 263-270.

4. Lawlor BA, Maurer RG: Tuberous sclerosis and the autistic syndrome. Br J Psychiatry 1987; 150: 396397.

5. Mouridsen SE, Andersen LB, Sörensen SA, Rich B, Isager T: Neurofibromatosis in infantile autism and other types of childhood psychoses. Acta Paedopsychiatr 1992; 55: 15-18.

6. Brown WT, Friedman E, Jenkins EC, et al.: Association of fragile $\mathrm{X}$ syndrome with autism. Lancet 1982; 1: 100.

7. Miladi N, Larnaout A, Kaabachi N, Helayem M, Ben Hamida M: Phenylketonuria: an underlying etiology of autistic syndrome. a case report. J Child Neurol 1992; 7: 22-23.

8. Money J: New phylism theory and autism: pathognomonic impairment of troopbonding. Med Hypotheses 1983; 11: 245-250.

9. Fernell E, Gillberg C, von Wendt L: Autistic symptoms in children with infantile hydrocephalus. Acta Paediatr Scand 1991; 80: 451-457.

10. Libbey JE, Sweeten TL, McMahon WM, Fujinami RS: Autistic disorder and viral infections. J Neurovirol 2005; 11: 1-10.

11. Markowitz PI: Autism in a child with congenital cytomegalovirus infection. J Autism Dev Disord 1983; 13: 249-253.

12. Riva D: The cerebellar contribution to language and sequential functions: evidence from a child with cerebellitis. Cortex 1998; 34: 279-287.

13. Shi L, Fatemi SH, Sidwell RW, Patterson PH: Maternal influenza infection causes marked bevavioral and pharmacological changes in the 
offspring. J Neurosci 2003; 23: 297-302.

14. Rasalam AD, Hailey $\mathrm{H}$, Williams JH, et al.: Characteristics of fetal anticonvulsant syndrome associated autistic disorder. Dev Med Child Neurol 2005; 47: 551-555.

15. Harris SR, MacKay LL, Osborn JA: Autistic behaviors in offspring of mothers abusing alcohol and other drugs: a series of case reports. Alcohol Clin Exp Res 1995; 19: 660-665.

16. Dufour-Rainfray D, Vourc'h P, Tourlet S, Guilloteau D, Chalon S, Andres CR: Fetal exposure to teratogens: evidence of genes involved in autism. Neurosci Biobehav Rev 2011; 35: 1254-1255.

17. Mason-Brothers A, Ritvo ER, Guze V, et al.: Pre-, peri-, and postnatal factors in 181 autistic patients from single and multiple incidence families. J Am Acad Child Adolesc Psychiatry 1987; 26: 39-42.

18. Fidler DJ, Bailey JN, Smalley SL: Macrocephaly in autism and other pervasive developmental disorders. Dev Med Child Neurol 2000; 42: 737-740.

19. Hanley HG, Stahl SM, Freedman DX : Hyperserotonemia and amine metabolites in autistic and retarded children. Arch Gen Psychiatry 1977; 34: 521-531.

20. Casanova MF, Buxhoeveden DP, Switala AE, Roy E: Minicolumnar pathology in autism. Neurology 2002; 58: 428-433.

21. Casanova MF, Buxhoevenden D, Gomez J: Disruption in the inhibitory architecture of the cell minicolumn: implications for autism. Neuroscientist 2003; 9: 496-507.

22. Casanova MF, van Kooten IA, Switala AE, et al: Minicolumnar abnormalities in autism. Acta Neuropathol (Berl) 2006; 112: 287-303.

23. Levisohn L, Cronin-Golomb A, Schmahmann JD: Neuropsychological consequences of cerebellar tumour resection in children: cerebellar cognitive affective syndrome in a paediatric population. Brain 2000; 123: 1041-1050.

24. Riva D, Giorgi C: The cerebellum contributes to higher functions during development: evidence from a series of children surgically treated for posterior fossa tumours. Brain 2000; 123: 1051-1061.

25. Schmahmann JD: Disorders of the cerebellum: ataxia, dysmetria of thought, and the cerebellar cognitive affective syndrome. J Neuropsychiatry Clin Neurosci 2004; 16: 367-378.

26. Courchesne E, Yeung-Courchesne R, Press GA, Hesselink JR, Jernigan TL: Hypoplasia of cerebellar vermal lobules VI and VII in autism. N Engl J Med 1988; 318: 1349-1354.

27. Hashimoto T, Tayama M, Miyazaki M, Murakawa K, Kuroda Y: Brainstem and cerebellar vermis involvement in autistic children. J Child Neurol 1993; 8: $149-153$.

28. Hodge SM, Makris N, Kennedy DN, et al: Cerebellum, language, and cognition in autism and specific language impairment. J Autism Dev Disord 2010; 40: 300-316.

29. Piven J, Arndt S: The cerebellum and autism. Neurology 1995; 45: 398-402.

30. Bauman ML, Kemper TL: Neuroanatomic observations of the brain in autism: a review and future directions. Int J Dev Neurosci 2005; 23: 183187.

31. Ritvo ER, Freeman BJ, Scheibel AB, et al:: Lower Purkinje cell counts in the cerebella of four autistic subjects: initial findings of the UCLA-NSAC Autopsy Research Report. Am J Psychiatry 1986; 143: 862866.

32. Fatemi SH, Halt AR, Realmuto G, et al.: Purkinje cell size is reduced in cerebellum of patients with autism. Cell Mol Nuerobiol 2002; 22: 171-175.

33. Fatemi SH, Stary JM, Halt AR, Realmuto GR: Dysregulation of Reelin and Bcl-2 proteins in autistic cerebellum. J Autism Dev Disord 2001; 31: 529-535.

34. Riva D, Pantaleoni C, Milani N, Fossati Belani F: Impairment of neuropsychological functions in children with medulloblastomas and astrocytomas in the posterior fossa. Childs Nerv Syst 1989; 5: 107110 .

(Received, October 20, 2011)

(Accepted, November 9, 2011) 